\title{
Synthesis, Characterization and Antimicrobial Activity of Some Novel Quinoline Derivatives Bearing Pyrazole and Pyridine Moieties
}

\author{
Atef M. Amer ${ }^{1 *}$, Wafaa I. El-Eraky ${ }^{2}$ and Sebaey Mahgoub ${ }^{3}$ \\ ${ }^{1}$ Department of Chemistry, Faculty of Science, Zagazig University, Egypt. \\ ${ }^{2}$ Department of Pharmacology, National Research Centre, Cairo, Egypt. \\ ${ }^{3}$ Research and Development, Unipharma, El-Obour City, Egypt.
}

\begin{abstract}
$\mathrm{N}$ continuation of our interest in synthesis of novel quinoline derivatives with anticipated biological activity, we have synthesized new quinoline derivatives bearing pyrazole and pyridine moieties by formylation of quinoline hydrazones through the Vilsmeier-Haack reaction which is a common method for the synthesis of 4-formyl pyrazoles. Condensation of 2-hydrazinylquinoline 1 with 4-substituted acetophenone gave the corresponding hydrazones 2a-c which in turn underwent the Vilsmeier-Haack reaction in $\mathrm{POCl}_{3} / \mathrm{DMF}$ to furnish the corresponding 4-formyl pyrazole derivatives 3a-c. One-pot reaction of compounds 3a-c with malononitrile and thiophenol or ethyl mercaptan gave the 3,5-pyridine dicarbonitrile derivatives 11a-f. The synthesized derivatives were screened for their antimicrobial activities against Gram negative bacteria, Gram positive bacteria and Fungi. Most of compounds showed excellent antimicrobial activities compared to the reference drugs. All the newly synthesized compounds have been characterized by means of elemental analyses, IR, ${ }^{1} \mathrm{H}$ NMR and MS.
\end{abstract}

Keywords: Quinoline, Vilsmeier-Haackreaction, 4-Formylpyrazole,3,5-Pyridinedicarbonitrile, Antimicrobial activity.

\section{Introduction}

Quinoline derivatives have attracted considerable interest for many years due to their chemical reactivity and biological activity [1-4]. Literature surveys revealed that these derivatives possesses anti-inflammatory $[5,6]$ antimicrobial $[7,8]$, antimalarial $[9,10]$, antioxidant $[11,12]$, antitumor $[13,14]$, antiprotozoal [15], antituberculosis [16, 17] and antiulcer activity [18], as well as, A3 adenosine receptor antagonists [19]. On the other hand, pyrazole derivatives are known to exhibit diverse biological activities including anti-inflammatory [20], anticancer [21] and antimicrobial [22, 23] activity. Also, many pyridine dicarbonitrile derivatives were reported to have significant biological activity such as anti-inflammatory and analgesic activities [24]. In the light of these mentioned facts and our interest in designing new biologically active molecules, our efforts were directed towards the synthesis of new heterocyclic compounds containing quinoline ring bearing pyrazole and pyridine moieties with anticipated biological activities.

\section{Experimental}

General

All melting points were determined in openglass capillaries and are uncorrected. IR spectra were recorded on a Bruker Vector 22 Germany spectrometer (KBr). ${ }^{1} \mathrm{HNMR}$ spectra were recorded on Bruker $400 \mathrm{MHz}$ spectrometer using TMS as an internal reference. The Electron Impact mass spectrometry was obtained at 70 eV using Shimadzu QP-2010 Plus mass spectrometer. The reactions were monitored by thin-layer chromatography (TLC) on silica gel F254 aluminum sheets (Merck), and the spots were visualized by UV lamp at 254-365 $\mathrm{nm}$.

*Corresponding author e-mail: atefamer55@yahoo.com 


\section{Preparation of 2-hydrazinylquinoline $\mathbf{1}$}

2-Chloroquinoline (1.0 g, $6.1 \mathrm{mmol})$ and hydrazine monohydrate $(3 \mathrm{~mL})$ in $\mathrm{n}$-butanol $(10$ $\mathrm{mL}$ ) were refluxed for $6 \mathrm{~h}$. The solvent was removed under reduced pressure giving a brownish orange residue, the residue was triturated with ethanol then filtered to give compound $\mathbf{1}$, orange crystals, yield $86.5 \%$; mp $140-142{ }^{\circ} \mathrm{C}$; IR $\left(\mathrm{KBr}, \mathrm{cm}^{-1}\right)$ : 3282, $3188(\mathrm{NH}), 3042\left(\mathrm{CH}_{\text {arom }}\right), 1621(\mathrm{C}=\mathrm{N})$.

General procedure for the synthesis of (E)-2(2-(1-(4-substituted)ethylidene)hydrazineyl) quinoline derivatives $\mathbf{2 a - c}$

A mixture of compound 1 (1.0 g, $6.3 \mathrm{mmol})$ and substituted acetophenone $(6.3 \mathrm{mmol})$, was refluxed in ethanol $(20 \mathrm{~mL})$ containing (1 $\mathrm{mL}$ ) of hydrochloric acid for $6 \mathrm{~h}$. The solvent was reduced to its half, and allowed to cool. The separated solid was filtered, dried, and recrystallized from ethanol.

(E)-2-(2-(1-phenylethylidene) hydrazineyl) quinoline $\mathbf{2 a}$

Yellow solid; yield $86 \%$; mp $160-162{ }^{\circ} \mathrm{C}$; IR $\left(\mathrm{KBr}, \mathrm{cm}^{-1}\right): 3431(\mathrm{NH}), 3106\left(\mathrm{NH}_{\text {stretch }}\right), 2966$ $\left(\mathrm{CH}_{\text {aliph }}\right), 1599(\mathrm{C}=\mathrm{N})$; $\mathrm{MS}(\mathrm{m} / \mathrm{z}): 261\left[\mathrm{M}^{+}\right.$, $0.06 \%$ ], Anal. Calcd for $\mathrm{C}_{17} \mathrm{H}_{15} \mathrm{~N}_{3}$ (261.33): C, 78.13; H, 5.79; N, 16.08. Found: C, 77.98; H, 5.64; N, 15.93 .

(E) - 2-(2-(1-(p-tolyl)ethylidene) hydrazineyl)quinoline $\mathbf{2 b}$

Yellow solid; yield $83 \%$; mp $230-232{ }^{\circ} \mathrm{C}$; IR $\left(\mathrm{KBr}, \mathrm{cm}^{-1}\right): 3406(\mathrm{NH}), 3032\left(\mathrm{CH}_{\text {aromatic }}\right)$, 2919, $2854\left(\mathrm{CH}_{\text {aliph }}\right), 1582(\mathrm{C}=\mathrm{N}) ; \mathrm{MS}(\mathrm{m} / \mathrm{z})$ : $275\left[\mathrm{M}^{+}, 1.10 \%\right]$, Anal. Calcd for $\mathrm{C}_{18} \mathrm{H}_{17} \mathrm{~N}_{3}$ (275.36): C, 78.52; H, 6.22; N, 15.26. Found: C, 78.38; H, 6.08; N, 15.12 .

(E)-2-(2-(1-(4-chlorophenyl)ethylidene) hydrazineyl) quinoline $\mathbf{2 c}$

Grey solid; yield $82 \%$; mp $228-230{ }^{\circ} \mathrm{C}$; IR $\left(\mathrm{KBr}, \mathrm{cm}^{-1}\right): 3433(\mathrm{NH}), 3104\left(\mathrm{NH}_{\text {stretch }}\right), 2968$ $\left(\mathrm{CH}_{\text {aliph }}\right), 1599(\mathrm{C}=\mathrm{N}), \mathrm{MS}(\mathrm{m} / \mathrm{z}): 295\left[\mathrm{M}^{+}, 0.43\right.$ \%], Anal. Calcd for $\mathrm{C}_{17} \mathrm{H}_{14} \mathrm{ClN}_{3}$ (295.77): C, 69.04; H, 4.77; N, 14.21. Found: C, 68.91; H, 4.64; N, 14.08 .

General procedure for the synthesis of 3-(4-aryl)1-(quinolin-2-yl)-1H-pyrazole-4-carbaldehyde 3a-c

A cold solution of hydrazone derivatives 2a-c $(1.0 \mathrm{~g})$ in dry DMF $(10 \mathrm{~mL})$ was added drop wise to the Vilsmeier-Haack reagent prepared from DMF $(15 \mathrm{~mL})$ and $\mathrm{POCl}_{3}(3 \mathrm{~mL})$ at $0^{\circ} \mathrm{C}$. The reaction mixture was stirred at $70^{\circ} \mathrm{C}$ for 5

Egypt.J.Chem. Special Issue (2018) hrs and poured into ice cold water. The solid separated was filtered, washed with water and recrystallized from ethanol to give compounds 3a-c.

3-Phenyl-1-(quinolin-2-yl)-1H-pyrazole-4carbaldehyde $\mathbf{3 a}$

White solid; yield $80 \%$; mp $158-160{ }^{\circ} \mathrm{C}$; IR $\left(\mathrm{KBr}, \mathrm{cm}^{-1}\right)$ : $3041\left(\mathrm{CH}_{\text {arom }}\right), 2924,2827(\mathrm{CH}$ stretching $), 1680(\mathrm{C}=\mathrm{O}), 1595,1508(\mathrm{C}=\mathrm{N}) ; \mathrm{MS}$ $(\mathrm{m} / \mathrm{z}): 299\left[\mathrm{M}^{+}, 0.23\right] ;{ }^{1} \mathrm{H}$ NMR (DMSO-d6): $\delta$ $(\mathrm{ppm})=10.11(\mathrm{~s}, 1 \mathrm{H}, \mathrm{CHO}), 9.6(\mathrm{~s}, 1 \mathrm{H},=\mathrm{CH}$ pyrazole), 8.69 (d, 1H, H4 quinoline), 8.30-7.59 (m, 10H, Ar-H).Anal. Calcd for $\mathrm{C}_{19} \mathrm{H}_{13} \mathrm{~N}_{3} \mathrm{O}$ (299.33): C, 76.24; H, 4.38; N, 14.04. Found: C, $76.10 ; \mathrm{H}, 4.24 ; \mathrm{N}, 13.90$.

1-(Quinolin-2-yl)-3-(p-tolyl)-1H-pyrazole-4carbaldehyde $\mathbf{3 b}$

White solid; yield $79 \%$; mp $189-191{ }^{\circ} \mathrm{C}$; IR ( $\left.\mathrm{KBr}, \mathrm{cm}^{-1}\right)$ : $3038\left(\mathrm{CH}_{\text {arom }}\right), 2963\left(\mathrm{CH}_{\text {aliph }}\right)$, 2914, $2858\left(\mathrm{CH}_{\text {stretching }}\right), 1678(\mathrm{C}=\mathrm{O}), 1597,1508$ $(\mathrm{C}=\mathrm{N})$; MS (m/z): $313\left[\mathrm{M}^{+}, 0.03 \%\right] ;{ }^{1} \mathrm{H} \mathrm{NMR}$ $(\mathrm{DMSO}-\mathrm{d} 6): \delta(\mathrm{ppm})=10.11(\mathrm{~s}, 1 \mathrm{H}, \mathrm{CHO}), 9.6$ $(\mathrm{s}, 1 \mathrm{H},=\mathrm{CH}$ pyrazole), 8.69 (d, $1 \mathrm{H}, \mathrm{H} 4$ quinoline), 8.30-7.59 (m, 9H, Ar-H), 2.25 (s, 3H, $\mathrm{CH}_{3}$ ). Anal. Calcd for $\mathrm{C}_{20} \mathrm{H}_{5} \mathrm{~N}_{3} \mathrm{O}$ (313.36): C, 76.66; H, 4.83; N, 13.41. Found: C, 76.51; H, 4.68; N, 13.26.

3-(4-Chlorophenyl)-1-(quinolin-2-yl)-1Hpyrazole-4-carbaldehyde 3c

Yellow solid; yield $89 \%$; mp $180-182{ }^{\circ} \mathrm{C}$; IR $\left(\mathrm{KBr}, \mathrm{cm}^{-1}\right): 3046\left(\mathrm{CH}_{\text {arom }}\right), 2920,2823(\mathrm{CH}$ )$, 1648(\mathrm{C}=\mathrm{O}), 1538(\mathrm{C}=\mathrm{N}) ; \mathrm{MS}(\mathrm{m} / \mathrm{z}): 333$ stretching $\left.\mathrm{M}^{+}, 0.98 \%\right], 144\left[\right.$ Base peak, 100\%]; ${ }^{1} \mathrm{H}$ NMR $(\mathrm{DMSO}-\mathrm{d} 6): \delta(\mathrm{ppm})=10.11(\mathrm{~s}, 1 \mathrm{H}, \mathrm{CHO}), 9.6$ (s, 1H, =CHpyrazole), 8.69 (d, 1H, H4quinoline), 8.30-7.59 (m, 9H, Ar-H).Anal. Calcd for $\mathrm{C}_{19} \mathrm{H}_{12} \mathrm{ClN}_{3} \mathrm{O}$ (333.78): C, 68.37; H, 3.62; N, 12.59. Found: C, 68.24; H, 3.46; N, 12.43.

General procedure for the synthesis of 2-amino4-(3-(4-aryl)-1-(quinolin-2-yl)-1H-pyrazol-4-yl)6-(alkylthio)pyridine-3,5-dicarbonitrile 11a-f

Aldehyde derivatives 3a-c (1 $\mathrm{mmol})$, malononitrile $(2 \mathrm{mmol})$, thiophenol or mercapto ethanol $(1 \mathrm{mmol})$ and few drops of piperidine were mixed in ethanol and refluxed for $1 \mathrm{~h}$. to the completion of reaction (monitored by TLC). The reaction mixture was cooled and precipitate formed was filtered and recrystallized from ethanol to yield the pure product.

2-Amino-4-(3-phenyl-1-(quinolin-2-yl)1 H-pyrazol-4-yl)-6-(phenylthio)pyridine-3,5dicarbonitrile 11a

Yellow solid; yield $76 \%$; mp $160-162{ }^{\circ} \mathrm{C}$; 
IR ( $\left.\mathrm{KBr}, \mathrm{cm}^{-1}\right): 3423,3211\left(\mathrm{NH}_{2}\right), 3057\left(\mathrm{CH}_{\text {arom }}\right)$, 2924, 2849 ( $\mathrm{CH}$ stretching $), 2359,2202(\mathrm{C} \equiv \mathrm{N})$, 1623, $1557(\mathrm{C}=\mathrm{N})$; MS (m/z): $521\left[\mathrm{M}^{+}, 1.06 \%\right.$ ]; ${ }^{1} \mathrm{H}-\mathrm{NMR}(\mathrm{DMSO}-\mathrm{d} 6): \delta(\mathrm{ppm})=9.23(\mathrm{~s}, 1 \mathrm{H},=\mathrm{CH}$ pyrazole), 8.69 (d, 1H, H4 quinoline), 8.34-7.39 (m, 15H, Ar-H), 4.36 (s, 2H, $\mathrm{NH}_{2}$ ). Anal. Calcd for $\mathrm{C}_{31} \mathrm{H}_{19} \mathrm{~N}_{7} \mathrm{~S}$ (521.60): C, 71.38; H, 3.67; N, 18.80 . Found: C, 71.23; H, 3.52; N, 18.65 .

2-Amino-6-(ethylthio)-4-(3-phenyl-1(quinolin-2-yl)-1H-pyrazol-4-yl)pyridine-3,5dicarbonitrile 11b

Yellow solid; yield $73 \%$; mp 278-280 ${ }^{\circ} \mathrm{C}$; IR $\left(\mathrm{KBr}, \mathrm{cm}^{-1}\right)$ : 3346, $3178\left(\mathrm{NH}_{2}\right), 3058\left(\mathrm{CH}_{\text {arom }}\right)$, 2966, ( $\left.\mathrm{CH}_{\text {aliph }}\right) 2926,2881$ ( $\mathrm{CH}$ stretching), 2360, 2218 (CN), 1607, $1590(\mathrm{C}=\mathrm{N}),{ }^{1} \mathrm{H}-\mathrm{NMR}$ $(\mathrm{DMSO}-\mathrm{d} 6): \delta(\mathrm{ppm})=9.23(\mathrm{~s}, 1 \mathrm{H},=\mathrm{CH}$ pyrazole), 8.69 (d, 1H, H4 quinoline), 8.34-7.45 (m, 10H, Ar-H), 4.36 (s, 2H, NH $), 3.43$ (q, 2H, $\left.\mathrm{CH}_{2}\right), 1.35\left(\mathrm{t}, 3 \mathrm{H}, \mathrm{CH}_{3}\right)$. MS (m/z): $473\left[\mathrm{M}^{+}, 0.07\right.$ \%], Anal. Calcd for $\mathrm{C}_{27} \mathrm{H}_{19} \mathrm{~N}_{7} \mathrm{~S}$ (473.56): C, 68.48; H, 4.04; N, 20.70. Found: C, 68.32; H, 3.88; N, 20.54 .

2-Amino-6-(phenylthio)-4-(1-(quinolin-2yl)-3-(p-tolyl)-1H-pyrazol-4-yl)pyridine-3,5dicarbonitrile 11c

Yellow solid; yield $77 \%$; mp 210-212 ${ }^{\circ} \mathrm{C}$; IR $\left(\mathrm{KBr}, \mathrm{cm}^{-1}\right)$ : $3441,3306\left(\mathrm{NH}_{2}\right), 3062\left(\mathrm{CH}_{\text {arom }}\right)$, 2209, $2135(\mathrm{CN}), 1544,1509(\mathrm{C}=\mathrm{N})$; $\mathrm{MS}(\mathrm{m} / \mathrm{z})$ : $535\left[\mathrm{M}^{+}, 0.62 \%\right] ;{ }^{1} \mathrm{H}-\mathrm{NMR}$ (DMSO-d6): $\delta$ (ppm) $=9.23(\mathrm{~s}, 1 \mathrm{H},=\mathrm{CH}$ pyrazole $), 8.69(\mathrm{~d}, 1 \mathrm{H}, \mathrm{H} 4$ quinoline), 8.34-7.45 (m, 14H, Ar-H), 4.36 (s, $\left.2 \mathrm{H}, \mathrm{NH}_{2}\right), 2.35\left(\mathrm{~s}, 3 \mathrm{H}, \mathrm{CH}_{3}\right)$. Anal. Calcd for $\mathrm{C}_{32} \mathrm{H}_{21} \mathrm{~N}_{7} \mathrm{~S}$ (535.63): C, 71.76; H, 3.95; N, 18.31 . Found: C, 71.60; H, 3.79; N, 18.15 .

2-Amino-6-(ethylthio)-4-(1-(quinolin-2yl)-3-(p-tolyl)-1H-pyrazol-4-yl)pyridine-3,5dicarbonitrile 11d

Yellow solid; yield $80 \%$; mp 260-262 ${ }^{\circ} \mathrm{C}$; IR $\left(\mathrm{KBr}, \mathrm{cm}^{-1}\right)$ : 3385, $3166\left(\mathrm{NH}_{2}\right), 3052\left(\mathrm{CH}_{\text {arom }}\right)$, $2965\left(\mathrm{CH}_{\text {aliph }}\right), 2925,2848$ (CH stretching), 2210 , $2150(\mathrm{CN}), 1551,1508(\mathrm{C}=\mathrm{N}) ; \mathrm{MS}(\mathrm{m} / \mathrm{z}): 487$ $\left[\mathrm{M}^{+}, 1.00 \%\right],{ }^{1} \mathrm{H}-\mathrm{NMR}$ (DMSO-d6): $\delta$ (ppm) $=9.23(\mathrm{~s}, 1 \mathrm{H},=\mathrm{CH}$ pyrazole $), 8.69(\mathrm{~d}, 1 \mathrm{H}, \mathrm{H} 4$ quinoline), 8.34-7.45 (m, 9H, Ar-H), $4.36(\mathrm{~s}, 2 \mathrm{H}$, $\left.\mathrm{NH}_{2}\right), 3.43$ (q, 2H, $\left.\mathrm{CH}_{2}\right), 2.3\left(\mathrm{~s}, 3 \mathrm{H}, \mathrm{CH}_{3}\right) 1.35$ (t, $3 \mathrm{H}, \mathrm{CH}_{3}$ ). Anal. Calcd for $\mathrm{C}_{28} \mathrm{H}_{21} \mathrm{~N}_{7} \mathrm{~S}$ (487.59): C, 68.97; H, 4.34; N, 20.11. Found: C, 68.82; H, 4.19; N, 19.96.

2-Amino-4-(3-(4-chlorophenyl)-1-(quinolin2-yl)-1H-pyrazol-4-yl)-6-(phenylthio)pyridine3,5-dicarbonitrile 11e

Yellow solid; yield $81 \%$; mp 210-212
${ }^{\circ} \mathrm{C}$; IR (KBr, cm $\left.{ }^{-1}\right): 3396,3216\left(\mathrm{NH}_{2}\right), 3059$ $\left(\mathrm{CH}_{\text {arom }}\right), 2929,2849$ (CH stretching), 2206, 2159 $(\mathrm{CN}), 1607,1558(\mathrm{C}=\mathrm{N}) ; \mathrm{MS}(\mathrm{m} / \mathrm{z}): 556\left[\mathrm{M}^{+}, 2.16\right.$ $\%$; ${ }^{1} \mathrm{H}-\mathrm{NMR}(\mathrm{DMSO}-\mathrm{d} 6): \delta(\mathrm{ppm})=9.23(\mathrm{~s}, 1 \mathrm{H}$, $=\mathrm{CH}$ pyrazole), 8.69 (d, 1H, $\mathrm{H} 4$ quinoline), 8.34 7.45 (m, 14H, Ar-H). Anal. Calcd for $\mathrm{C}_{31} \mathrm{H}_{18} \mathrm{ClN}_{7} \mathrm{~S}$ (556.04): C, 66.96; H, 3.26; N, 17.63. Found: C, $66.82 ; \mathrm{H}, 3.12 ; \mathrm{N}, 17.49$.

2-Amino-4-(3-(4-chlorophenyl)-1-(quinolin2-yl)-1H-pyrazol-4-yl)-6-(ethylthio)pyridine-3,5dicarbonitrile $\mathbf{1 1 f}$

Yellow solid; yield $97 \%$; mp260-262 ${ }^{\circ} \mathrm{C}$; IR $\left(\mathrm{KBr}, \mathrm{cm}^{-1}\right): 3343,3193\left(\mathrm{NH}_{2}\right), 3059\left(\mathrm{CH}_{\text {arom }}\right)$, 2923, 2843 (CH stretching), 2215, 2153(CN), $1597(\mathrm{C}=\mathrm{N})$; $\mathrm{MS}(\mathrm{m} / \mathrm{z}): 508 \quad\left[\mathrm{M}^{+}, 0.56 \%\right.$; ${ }^{1} \mathrm{H}-\mathrm{NMR}$ (DMSO-d6): $\delta(\mathrm{ppm})=9.23(\mathrm{~s}, 1 \mathrm{H}$, $=\mathrm{CH}$ pyrazole $), 8.69(\mathrm{~d}, 1 \mathrm{H}, \mathrm{H} 4$ quinoline $)$, 8.34-7.45 (m, 9H, Ar-H), $4.36\left(\mathrm{~s}, 2 \mathrm{H}, \mathrm{NH}_{2}\right)$, $3.43\left(\mathrm{q}, 2 \mathrm{H}, \mathrm{CH}_{2}\right), 1.35\left(\mathrm{t}, 3 \mathrm{H}, \mathrm{CH}_{3}\right)$. Anal. Calcd for $\mathrm{C}_{27} \mathrm{H}_{18} \mathrm{ClN}_{7} \mathrm{~S}$ (508.00): C, 63.84; H, 3.57; N, 19.30. Found: C, 63.68; H, 3.41; N, 19.14.

\section{Antimicrobial activity}

The new compounds were evaluated for their antibacterial activities against two Gram positive bacteria (Staphelococcus aureus ATCC 6538 and B. subtilis ATCC6633), two Gram negative bacteria (Salmonellatyphimurium ATCC14028 and E. coli ATCC 8739) at a concentration 100 $\mu \mathrm{g} / \mathrm{ml}$. Also, the derivatives were tested for their antifungal activities against (Candida albicans ATCC10231). Dimethylsulfoxide was used as a solvent for tested compounds and was used as a negative control. Ciprofloxacin and Ketoconazole at concentration of $100 \mu \mathrm{g} / \mathrm{mL}$ in dimethylsulfoxide were used as positive control. After incubation period, the growth inhibition zones diameters were carefully measured in $\mathrm{mm}$.

\section{Results and Discussion}

Synthesis of target compounds (11a-f) was achieved as outlined in (Schemes 1 and 3). The starting material 2-hydrazinylquinoline $\mathbf{1}$ was synthesized in a high yield from the reaction of hydrazine hydrate with 2-chloroquinoline in refluxing n-butanol, through procedures similar to the previously reported method [25] and its modification [26]. Structure of compound 1 was confirmed by its IR spectrum that revealed presence of two bands at $3282,3188 \mathrm{~cm}^{-1}$ corresponding to $\mathrm{NH}$ groups and two bands at $3042,1621 \mathrm{~cm}^{-1}$ corresponding aromatic $\mathrm{CH}$ and $\mathrm{C}=\mathrm{N}$, respectively. The melting point of the compound was close to the reported values $\left(140-142^{\circ} \mathrm{C}\right)$. Reaction of Egypt.J.Chem. Special Issue (2018) 
compound 1 with 4-substituted acetophenone in $(1: 1)$ molar ratio afforded the corresponding 2-(2-(1-arylethylidene-hydrazineyl- quinoline derivatives $\mathbf{2 a}-\mathbf{c}$ in a good yield. Structures of compounds $\mathbf{2 a - c}$ were supported by their elemental analysis and spectral data. IR spectra of compounds 2a-c showed peaks at 3431-3435, 3104-3108 $\mathrm{cm}^{-1}$ corresponding to $\mathrm{NH}$ groups and absorption peaks at $2966-2968 \mathrm{~cm}^{-1}$ due to aliphatic $\mathrm{CH}$ as well as other peaks at 1599-1601 $\mathrm{cm}^{-1}$ corresponding to $\mathrm{C}=\mathrm{N}$ groups. Mass spectra of all derivatives showed the molecular ion peaks which were in agreement with their molecular formula.

Solution of derivatives $\mathbf{2 a - c}$ in DMF was added to a mixture of Vilsmeier-Haack reagent and the solution was stirred towards the completion of reaction, leading to formation of 3-(4-aryl)1-(quinolin-2-yl)-1H-pyrazole-4-carbaldehyde derivatives 3a-c. A proposed mechanism for the formation of 4-formylyrazoles is outlined in (Scheme 2) [27]. Initial electrophilic attack of Vilsmeier-Haack reagent $\mathbf{4}$ on hydrazone $\mathbf{2}$ yielded the intermediate $\mathbf{5}$ which subsequently loses a molecule of $\mathrm{HCl}$ to provide intermediate 6. Then the nucleophilic attack by $\mathrm{NH}$ group initiates the cyclisation and the resulting pyrazoline immediately, loses $\mathrm{Me}_{2} \mathrm{NH}$ to give the more stable pyrazole derivatives 7 . The pyrazole 7 reacts with another mole of Vilsmeier-Haack reagent $\mathbf{4}$ in an electrophilic substitution process giving an iminium salt $\mathbf{8}$, which is hydrolyzed to the corresponding 4-formylpyrazoles $\mathbf{3 a - c}$.
Formation of compounds 3a-c was supported by their IR spectra that showed peaks at 2920-2823 and $1648-1680 \mathrm{~cm}^{-1}$ corresponding to $\mathrm{CH}$ and $\mathrm{C}=\mathrm{O}$ stretching respectively and there was no absorption bands at the $\mathrm{NH}$ region. Also, their ${ }^{1} \mathrm{H}$ NMR spectra showed two sharp singlet signals at $\delta 10.11 \mathrm{ppm}$ due to aldehydic proton of $-\mathrm{CHO}$ group and at $\delta 9.6 \mathrm{ppm}$ due to $=\mathrm{C}-\mathrm{H}$ of the pyrazole ring. On the other hand, the molecular ion peaks shown in the Mass spectra of all derivatives were in agreement with their molecular formula.

Derivatives 3a-c in turn react in one-pot with malononitrile and thiophenol or ethyl mercaptan in absolute ethanol added to it a few drops of piperidine to give 2-amino-4-(3-(4-aryl)-1(quinolin-2-yl)-1H-pyrazol-4-yl)-6-(alkylthio) pyridine-3,5-dicarbonitrile derivatives 11a-f (Scheme 3).

The mechanism of this reaction has been discussed in accordance with the mechanism suggested in literature [28], the first step of this process involves the Knoevenagel condensation of formylpyrazole derivative with malononitrile to form the corresponding 2-(1,3-substituted1H-pyrazol-4-yl)methylene)malononitrile 9; The second molecule of malononitrile then undergoes Michael addition to compound 9 followed by simultaneous thiolate addition to $-\mathrm{C} \equiv \mathrm{N}$ of the adduct and cyclization to dihydropyridine $\mathbf{1 0}$ which on aromatization and oxidation under the reaction conditions leads to pyridine derivatives 11a-f.

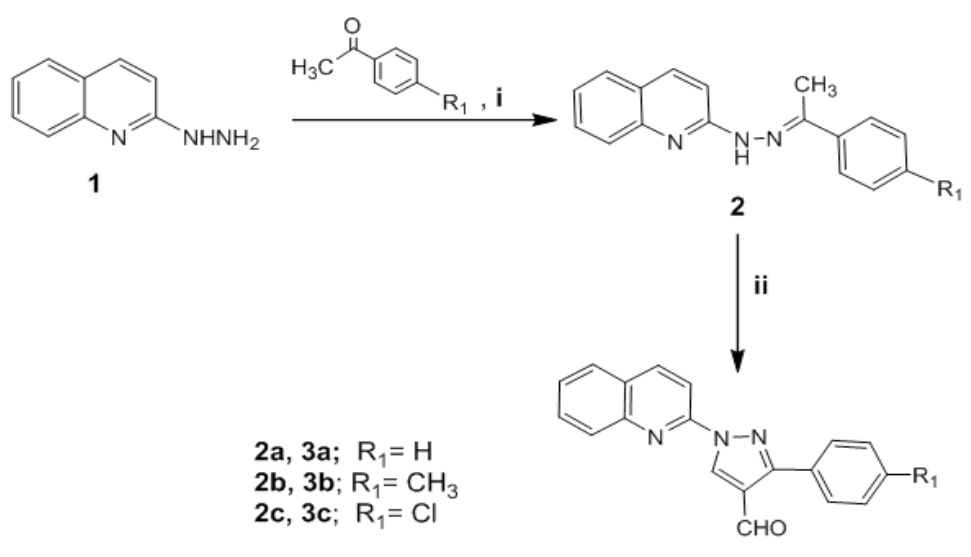

3

Scheme 1 Synthesis of derivatives 3a-c.

Reagents and conditions:i EtOH/HCl/reflux, ii DMF/ $\mathrm{POCl}_{3} / 70^{\circ} \mathrm{C}$

Egypt.J.Chem. Special Issue (2018) 


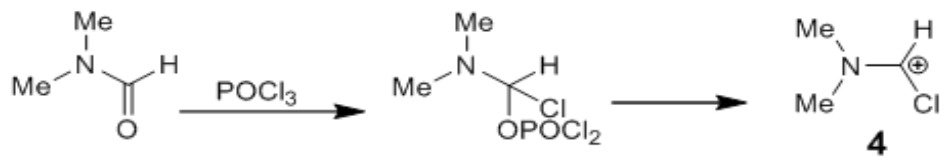

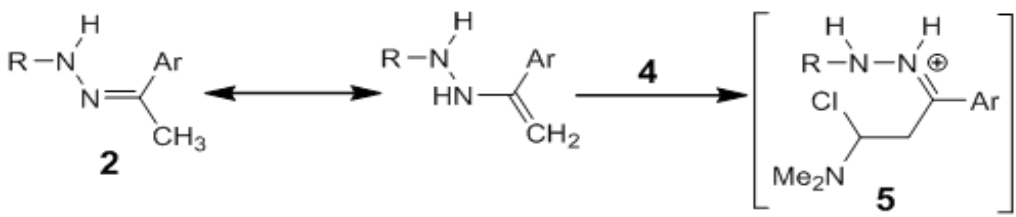

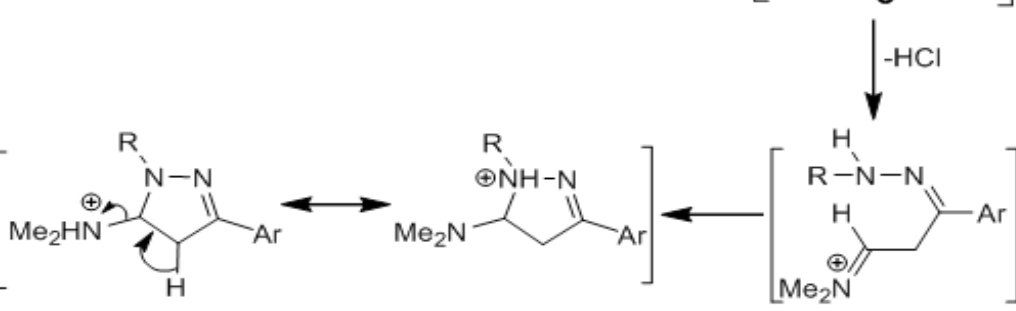

$\downarrow-\mathrm{Me}_{2} \mathrm{NH}_{2}$

6
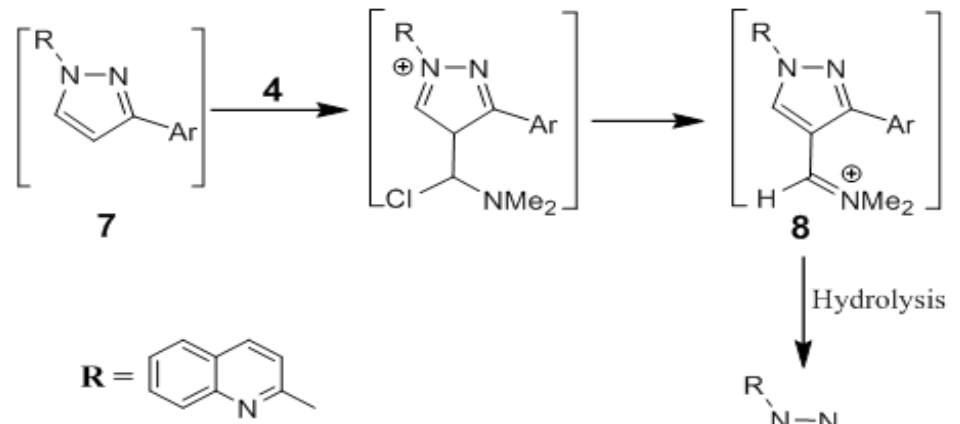

Hydrolysis

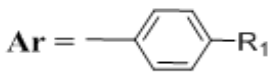

$\mathrm{R}$<smiles>Cn1nncc1C=O</smiles>

3

Scheme 2 Mechanism for the formation of 4-formylpyrazoles 3a-c

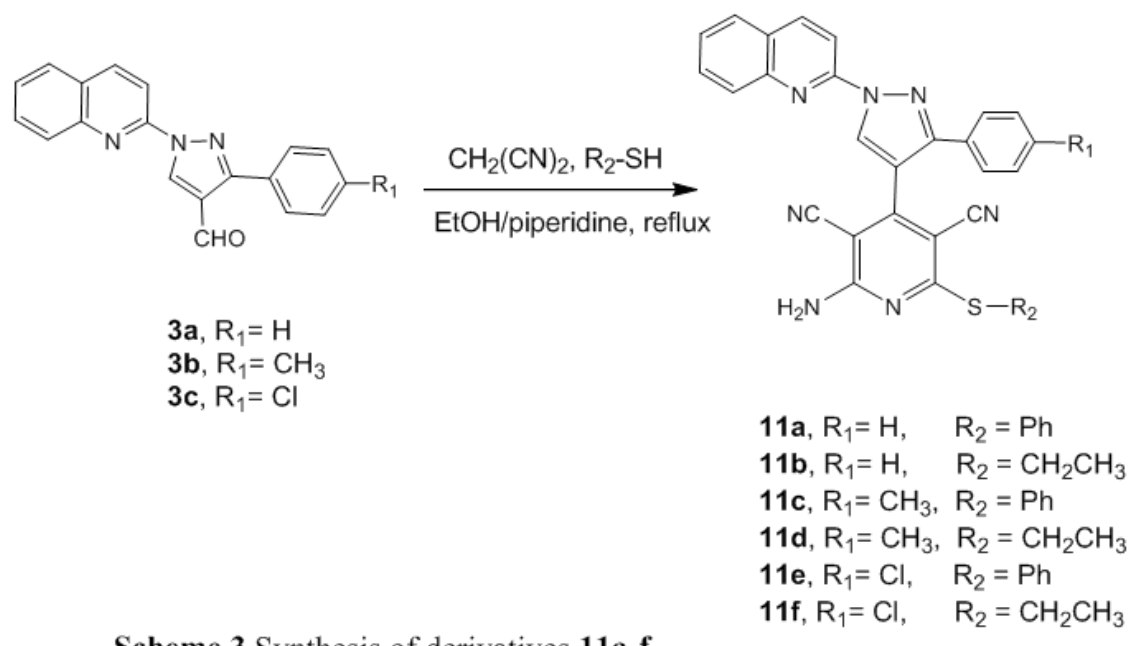

Scheme 3 Synthesis of derivatives 11a-f. 
Structures of compounds 11a-f were supported by their elemental analysis and spectral data too. Mass spectrometry of all derivatives showed the molecular ion peaks close to their expected values. Also, ${ }^{1} \mathrm{H}$ NMR spectra showed characteristic singlet signals at $\delta 9.23$ due to $=\mathrm{C}-\mathrm{H}$ of the pyrazole ring, besides other singlet signals at $\delta 4.36 \mathrm{ppm}$ which was assigned to $\mathrm{NH}_{2}$ group. IR spectra of compounds 11a-f have characteristic peaks at 3421-3396, 3216-3178 $\mathrm{cm}^{-1}$ due to $-\mathrm{NH}_{2}$ groups, and peaks at 2360-2159 $\mathrm{cm}^{-1}$ due to $-\mathrm{C} \equiv \mathrm{N}$ groups which in turn confirm the structure of target compounds.

\section{Antimicrobial activity}

New compounds were screened in vitro for their antibacterial activities against two Gram positive bacteria (Staphelococcus aureus ATCC 6538 and B. subtilis ATCC6633), two Gram negative bacteria (Salmonellatyphimurium ATCC14028 and E. coli ATCC 8739) at a concentration 100 $\mu \mathrm{g} / \mathrm{ml}$. Also, the derivatives were tested for their antifungal activities against (Candida albicans ATCC10231). Dimethylsulfoxide was used as a solvent for tested compounds and was used as a negative control showing no activity against tested microorganisms. Ciprofloxacin and Ketoconazole at concentration of $100 \mu \mathrm{g} / \mathrm{mL}$ in dimethylsulfoxide were used as positive control. Antimicrobial tests were carried out by the agar diffusion technique [29]. Table 1 summarizes the results of antimicrobial studies, in which compounds 3a-c and 11a-f exhibited excellent activity against Candida albicans compared to ketoconazole drug. On the other, hand compounds 3c and 11a-f possesses considerably broader antimicrobial activity compared to Ciprofloxacin. Rest of derivatives showed good to moderate activity against the tested microorganisms.

TABLE 1. In vitro anti-microbial activity of synthesized compounds expressed as inhibition zones (I.Z) diameter *

\begin{tabular}{|c|c|c|c|c|c|c|c|c|c|c|}
\hline \multirow{3}{*}{ Compound } & \multicolumn{4}{|c|}{ Gram +ve } & \multicolumn{4}{|c|}{ Gram -ve } & \multirow{2}{*}{\multicolumn{2}{|c|}{$\begin{array}{c}\text { Fungus } \\
\text { C. albicans } \\
\text { ATCC10231 }\end{array}$}} \\
\hline & \multicolumn{2}{|c|}{$\begin{array}{c}\text { S. aureus } \\
\text { ATCC6538 }\end{array}$} & \multicolumn{2}{|c|}{$\begin{array}{c}\text { B. subtilis } \\
\text { ATCC6633 }\end{array}$} & \multicolumn{2}{|c|}{$\begin{array}{c}\text { E. coli } \\
\text { ATCC8739 }\end{array}$} & \multicolumn{2}{|c|}{$\begin{array}{l}\text { S.typhimurium } \\
\text { ATCC14028 }\end{array}$} & & \\
\hline & I.Z & \%A.I** & I.Z & \%A.I & I.Z & \%A.I & I.Z & \%A.I & I.Z & \%A.I \\
\hline $3 a$ & $\mathrm{~N} / \mathrm{A}^{* * *}$ & 0 & 10 & $29 \%$ & 11 & $34 \%$ & 13 & $28 \%$ & 12 & $48 \%$ \\
\hline $3 b$ & N/A & 0 & 10 & $29 \%$ & 11 & $34 \%$ & 11 & $24 \%$ & 12 & $48 \%$ \\
\hline $3 c$ & N/A & 0 & 9 & $26 \%$ & 12 & $38 \%$ & 12 & $26 \%$ & 10 & $40 \%$ \\
\hline $11 \mathrm{a}$ & 11 & $28 \%$ & 12 & $34 \%$ & 13 & $41 \%$ & 11 & $24 \%$ & 14 & $56 \%$ \\
\hline $11 b$ & 11 & $28 \%$ & 13 & $37 \%$ & 14 & $44 \%$ & 11 & $24 \%$ & 13 & $52 \%$ \\
\hline $11 \mathrm{c}$ & 11 & $28 \%$ & 13 & $37 \%$ & 14 & $44 \%$ & 11 & $24 \%$ & 13 & $52 \%$ \\
\hline 11d & 10 & $25 \%$ & 11 & $32 \%$ & 12 & $38 \%$ & 15 & $33 \%$ & 13 & $52 \%$ \\
\hline $11 \mathrm{e}$ & 10 & $25 \%$ & 11 & $32 \%$ & 12 & $38 \%$ & 15 & $33 \%$ & 13 & $52 \%$ \\
\hline 11f & 10 & $25 \%$ & 11 & $32 \%$ & 12 & $38 \%$ & 14 & $31 \%$ & 12 & $48 \%$ \\
\hline Ciprofloxacin & 40 & $100 \%$ & 35 & $100 \%$ & 32 & $100 \%$ & 46 & $100 \%$ & 12 & $48 \%$ \\
\hline Ketoconazole & 18 & $45 \%$ & 13 & $37 \%$ & 20 & $62.5 \%$ & 14 & $31 \%$ & 25 & $100 \%$ \\
\hline
\end{tabular}

*Values are mean inhibition zone diameter $(\mathrm{mm})$ of three replicates.

** A.I activity index.

*** N/A no activity.

\section{Conclusion}

Nine derivatives were synthesized and in vitro evaluated for antibacterial activity against five pathogenic microorganisms. In conclusion these compounds possess a broad spectrum of activity against a group of bacteria, responsible for causing most common bacterial diseases. This paper opens the possibility of finding new effective bactericidal compounds.

\section{Acknowledgment}

Authors are grateful to Dr. Abdelhamid K. Ghamry, Microbiology Department, Unipharma, for his valuable discussion regarding the biological activity.

\section{$\underline{\text { References }}$}

1. Kouznetsov V.V., Méndez L.Y.V. and Gómez C.M.M., Recent progress in the synthesis of 
quinolines. Curr. Org. Chem. 9, 141-161 (2005).

2. Abdel-Wahab B.F., Khidre R.E., Farahat A.A. and El-Ahl A.A.S., 2-Chloroquinoline3-carbaldehydes: synthesis, reactions and applications. Arkivoc I, 211-276 (2012).

3. Madapa S., Tusi Z. and Batra S., Advances in the syntheses of quinoline and quinoline-annulaed ring systems. Curr. Org. Chem. 12, 1116-1183 (2008).

4. Marella A., Tanwar O.P., Saha R., Ali M.R., Srivastava S., Akhter M., Shaquiquzzaman M. and Alam M.M., Quinoline: A versatile heterocyclic. Saudi Pharm. J. 21(1), 1-12 (2013).

5. Wen X., Wang S.B., Liu D.C., Gong G.H. and Quan Z.S., Synthesis and evaluation of the antiinflammatory activity of quinoline derivatives. Med. Chem. Res. 24, 2591-2603 (2015).

6. Chen Y.L., Chen I.L., Lu C.M., Tzeng C.C., Tsao L.T. and Wang J.P., Synthesis and antiinflammatory evaluation of 4-anilinofuro[2,3-b] quinoline and 4-phenoxyfuro[2,3-b]quinoline derivatives, Part 3. Bioorganic Med. Chem. 12, 387-392 (2004).

7. Ozyanik M., Demirci S., Bektas H., Demirbas N., Demirbas A. and Karaoglu S.A., Preparation and antimicrobial activity evaluation of some quinoline derivatives containing an azole nucleus. Turk J. Chem. 36, 233 - 246 (2012).

8. Desai N.C., Maheta A.S., Rajpara K.M., Joshi V.V., Vaghani H.V. and Satodiya H.M., Green synthesis of novel quinoline based imidazole derivatives and evaluation of their antimicrobial activity. $J$. Saudi Chem. Soc.18(6), 963-971 (2014).

9. Baragana B., Norcross N.R., Wilson C., Porzelle A., Hallyburton I., Grimaldi R., Osuna-Cabello M., Norval S., Riley J., Stojanovski L., Simeons F.R.C., Wyatt P.G., Delves M.J., Meister S., Duffy S., Avery V.M., Winzeler E.A., Sinden R.E., Wittlin S., Frearson J.A., Gray D.W., Fairlamb A.H., Waterson D., Campbell S.F., Willis P., Read K.D. and Gilbert I.H., Discovery of a quinoline-4carboxamide derivative with a novel mechanism of action, multistage antimalarial activity and potent in vivo efficacy. J. Med. Chem. 59, 9672-9685 (2016).

10. Kaur K., Jain M., Reddy R.P. and Jain R., Quinolines and structurally related heterocycles as antimalarials. Eur. J. Med. Chem. 45, 3245-3264 (2010).
11. Hamama W.S., Hassanien A.E., El-Fedawy M.G. and Zoorob H.H., Synthesis, PM3-Semiempirical and biological evaluation of pyrazolo[4,3-c] quinolinones. J.Heterocycl. Chem. 53(3), 945-952 (2016).

12. Puskullu M.O., Tekiner B. and Suzen S., Recent studies of antioxidant quinoline derivatives. Mini Rev. Med. Chem.13(3), 365-372 (2013).

13. Tseng C.H., Chen Y.L., Chung K.Y., Wang C.H., Peng S.I., Cheng C.M. and Tzeng C.C., Synthesis and antiproliferative evaluation of 2,3-diarylquinoline derivatives. Org. Biomol. Chem. 9, 3205-3216 (2011).

14. Al-Dosari M.S., Ghorab M.M., Al-Said M.S. and Nissan Y.M., Discovering some novel 7-chloroquinolines carrying a biologically active benzenesulfonamide moiety as a new class of anticancer agents. Chem. Pharm. Bull. 61(1), 5058 (2013).

15. Salahuddin A., Inam A., van Zyl R.L., Heslop D.C., Chen C.T., Avecilla F., Agarwal S.M. and Azam A., Synthesis and evaluation of 7-chloro4-(piperazin-1-yl)quinolinesulfonamide as hybrid antiprotozoal agents. Bioorganic Med. Chem. 21, 3080-3089 (2013).

16. Eswaran S., Adhikari A.V., Chowdhury I.H., Pal N.K. and Thomas K.D., New quinoline derivatives: Synthesis and investigation of antibacterial and antituberculosis properties. Eur. J. Med. Chem. 45(8), 3374-3383 (2010).

17. Keri R.S. and Patil S.A., Quinoline: A promising antitubercular target. Biomed.Pharmacother. 68(8), 1161-1175 (2014).

18. Sashidhara K.V., Avula S.R., Mishra V., Palnati G.R., Singh L.R., Singh N., Chhonker Y.S., Swami P., Bhatta R.S. and palit G., Identification of quinoline-chalcone hybrids as potential antiulcer agents. Eur. J. Med. Chem. 89, 638-653 (2015).

19. Baraldi P.G., Tabrizi M.A., Preti D., Bovero A., Fruttarolo F., Romagnoli R., Zaid N.A., Moorman A.R., Varani K. and Borea P.A., New 2-arylpyrazolo[4,3-c]quinoline derivatives as potent and selective human A3 adenosine receptor antagonists. J. Med. Chem. 48, 5001-5008 (2005).

20. Bekhit A.A., Ashour H.M.A., Abdel-Ghany Y.S., Bekhit, A.D.A. and Baraka A., Synthesis and biological evaluation of some thiazolyl and thiadiazolyl derivatives of $1 \mathrm{H}$-pyrazole as antiinflammatory antimicrobial agents. Eur. J. Med.

Egypt.J.Chem. Special Issue (2018) 
Chem. 43, 456-463 (2008).

21. Christodoulou M.S., Liekens S., Kasiotis K.M. and Haroutounian S.A., Novel pyrazole derivatives: Synthesis and evaluation of anti-angiogenic activity.Bioorg. Med. Chem.18, 4338-4350(2010).

22. Bondock S., Fadaly W. and Metwally M.A., Synthesis and antimicrobial activity of some new thiazole, thiophene and pyrazole derivatives containing benzothiazole moiety. Eur. J. Med. Chem. 45, 3692-3701 (2010).

23. Amer A.M., Ghoneim A.A., Sherif M.H. and Farouk W., Synthesis and antimicrobial activities of new n-glycoside from phenyl pyrazole derivatives. Universal Journal of Chemistry 2(4), 53-58 (2014).

24. Hanaa M.H. and Mohamed M.A., Antiinflammatory and analgesic activities of some newly synthesized pyridine dicarbonitrile and benzopyranopyridine derivatives. Acta Pharm. 58, 175-186 (2008).

25. Gupta L.K., Bansal U. and Chandra S.,
Spectroscopic and physicochemical studies on nickel(II) complexes of isatin-3,2-quinolylhydrazones and their adducts. Spectrochim. Acta Part A66, 972-975 (2007).

26. Bin Najib M.H., Tan A.L., Young D.J., Ng S.W. and Tiekink E.R.T., 2-Hydrazinylquinoline. Acta. Cryst. E68 (7), 02138 (2012).

27. Singh K., Ralhan S., Sharma P.K., and Dhawan S.N., Vilsmeier-Haack reaction on hydrazones: a convenient synthesis of 4-formylpyrazoles. $J$. Chem. Res. 5, 316-318 (2005).

28. Evdokimov N.M., Magedov I.V., Kireev A.S. and Kornienko A., One step, three-component system of pyridine and 1,4-dihydropyridines with manifold medicinal utility. Org. Lett. 8(5), 899902 (2006).

29. Carrod L.P. and Grady F.D. Antibiotic and Chemotherapy, $3^{\text {rd }} \mathrm{ed}$, Churchill Livingestone Edinburgh, 477(1972).

(Received 25/5/2018; accepted 10/7/2018)

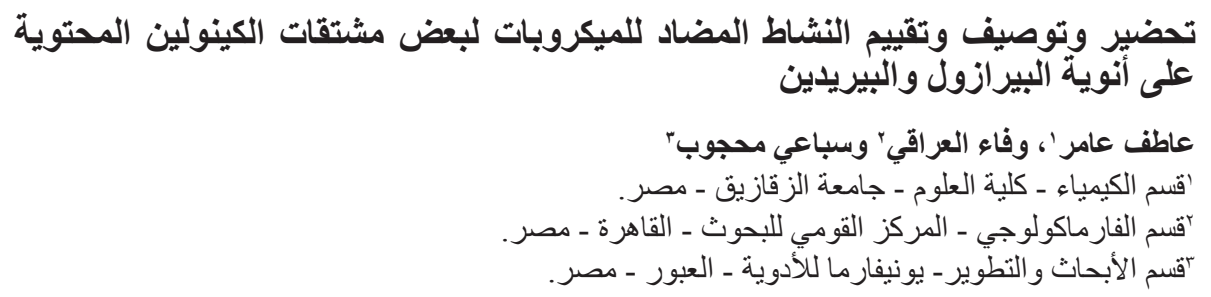

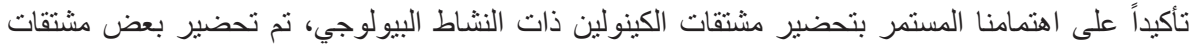

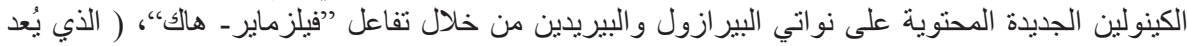

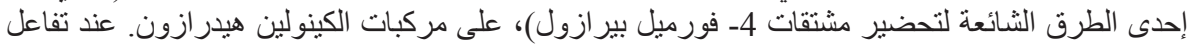

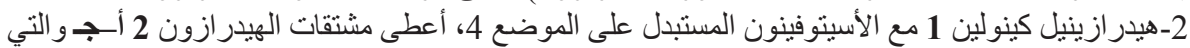

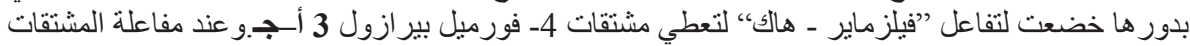

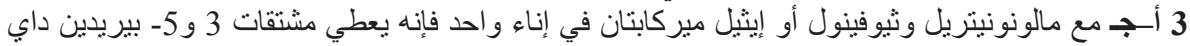

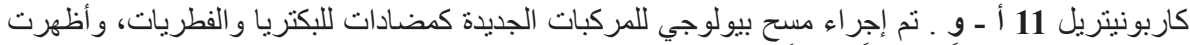

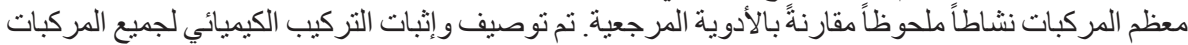

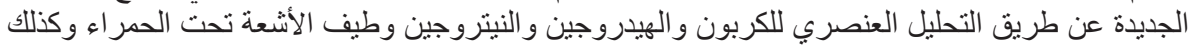
الرنين النووي المغناطيسي لنواة ذرة الهيدروجين إضافةً إلى تحليل طيف الكين الكتلة لجميع المركبات. 